DE

M E D I C I N A

T R O P I C A L

$\mathrm{DE}$

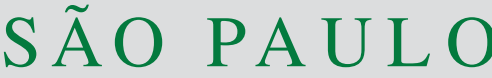

JOURNAL OF THE SÃO PAULO INSTITUTE OF TROPICAL MEDICINE

${ }^{1}$ Texas A\&M University College of Veterinary Medicine \& Biomedical Sciences, Department of Veterinary Integrative Biosciences, College Station, Texas, United States

2University of Oklahoma Health Sciences Center, Department of Biostatistics and Epidemiology, Oklahoma City, Oklahoma, United States

${ }^{3}$ Laboratorio Clinico de Enfemedades Neurodegeneraivas, Instituto Nacional de Neurología y Neurocirugía, Mexico DF, Mexico

${ }^{4}$ Hospital de Especialidades, Centro Medico Nacional Siglo XXI, Instituto Mexicano del Seguro Social, Mexico DF, Mexico

${ }^{5}$ Universidad Nacional Autonoma de Mexico, Facultad de Medicina, Departamento de Microbiologia y Parasitologia, Mexico DF, Mexico.

Correspondence to: Rachana Bhattarai Texas A\&M University College of Veterinary Medicine \& Biomedical Sciences, Department of Veterinary Integrative Biosciences, 660 Raymond Stotzer Pkwy, 77843-4458, College Station, Texas, United States

E-mail: rdhungel@cvm.tamu.edu

Received: 24 November 2017

Accepted: $1^{\circ}$ March 2018

\section{Pre-hospitalization, hospitalization, and post-hospitalization costs of patients with neurocysticercosis treated at the Instituto Nacional de Neurologia y Neurocirugia (INNN) in Mexico City, Mexico}

\author{
Rachana Bhattarai ${ }^{1}$, Hélène Carabin ${ }^{2}$, Jose Flores-Rivera ${ }^{3}$, Teresa Corona ${ }^{3}$, \\ Jefferson V. Proaño ${ }^{4}$, Ana Flisser ${ }^{5}$, Christine M. Budke ${ }^{1}$
}

\section{ABSTRACT}

The objective of this study was to estimate the direct costs associated with the diagnosis and treatment of neurocysticercosis (NCC) during pre-hospitalization, hospitalization, and posthospitalization periods for $108 \mathrm{NCC}$ patients treated at the Instituto Nacional de Neurologia y Neurocirugia (INNN) in Mexico City, Mexico. Information on clinical manifestations, diagnostic tests, hospitalizations, surgical procedures, prescription medication, and other treatments was collected via medical chart reviews. Uncertain values for costs and frequency of treatments were imputed using bootstrap techniques. The average per-patient pre-hospitalization and hospitalization costs were US\$ 257 (95\% CI: 185 - 329) and US\$ 2,576 (95\% CI: 2,244 $-2,908)$, respectively. Post-hospitalization costs tended to decrease over time, with estimates for the first five years post-hospitalization of US\$ 475 (95\% CI: 423 - 527), US\$ 228 (95\% CI: 167 - 288), US\$ 157 (95\% CI: 111 - 202), US\$ 150 (95\% CI: 106 - 204), and US\$ 91 (95\% CI: 27 -154), respectively. NCC results in a significant economic burden for patients requiring hospitalization, with this burden continuing years post-hospitalization.

KEYWORDS: Cost. Hospitalization. Neurocysticercosis.

\section{INTRODUCTION}

Neurocysticercosis (NCC) is caused by the larval stage of Taenia solium. The disease occurs when a human inadvertently ingests parasite eggs that have been shed in the feces of a person infected with taeniasis, with the eggs developing into larvae in the central nervous system. NCC is predominantly found and considered endemic in Latin American, Asian, and African countries where pigs are raised using traditional methods, veterinary meat inspection is insufficient, and sanitation is poor ${ }^{1-3}$. It has also been increasingly diagnosed in higher income areas such as the United States, Western Europe, and Canada due to immigrants from endemic areas who may have taeniasis or cysticercosis ${ }^{4,5}$. In Mexico and other Latin American countries, NCC is considered one of the leading causes of epilepsy ${ }^{6,7}$.

In humans, NCC is associated with numerous clinical manifestations, including epilepsy, hydrocephalus, focal deficits, severe chronic headaches, increased intracranial pressure, dementia, vasculitis, and stroke ${ }^{8}$. These NCC-associated clinical manifestations have been shown to affect the patients' quality of life leading to poorer physical and mental health and important economic consequences ${ }^{9-12}$. Studies conducted in India, Peru, and Mexico have estimated the average direct and indirect costs per NCC patient under care ${ }^{9,13,14}$, while two studies from the United 
States and one from Chile evaluated hospital-associated charges for NCC patients ${ }^{15-17}$. However, the per-patient costs associated with pre-hospitalization, hospitalization, and post-hospitalization for NCC have not been evaluated.

Period-specific cost estimates will be crucial for policy makers to comprehensively understand the true economic impact of the disease in order to prioritize and allocate resources. Therefore, this study was conducted to better define direct costs associated with pre-hospitalization, hospitalization, and post-hospitalization for NCC patients seeking care at a referral hospital in Mexico City, Mexico, taking into consideration costs to the healthcare system as well as medication paid for by the patients themselves.

\section{MATERIALS AND METHODS}

\section{Study location}

This study was conducted in a referral hospital for adult neurological cases in Mexico City, Mexico: the Instituto Nacional de Neurologia y Neurocirugia (INNN). The INNN only accepts patients who do not have medical insurance coverage through their employment. NCC patients with employer-provided medical insurance are seen at a different referral hospital in Mexico City and are, therefore, not represented in the current study.

\section{Definition and study populations}

NCC was defined based on the presence of compatible cerebral lesions on a computed tomography (CT) scan, magnetic resonance imaging (MRI), or both ${ }^{18}$. Outpatients diagnosed with NCC and with a clinical appointment at the INNN between July 17 and December 7, 2007 were eligible to participate. Eligible patients were identified using outpatient appointment books, which allowed a research assistant to explain the study and ask for the patient's consent at the time of the appointment. NCC outpatients were sequentially invited to participate until at least 100 patients were enrolled. The medical charts of consenting patients were reviewed by a trained member of the research team (i.e., a Mexican intern, resident, or social worker). Only patients alive at the time of recruitment and who were hospitalized for the treatment of NCC between January 2002 and August 2007 were included in this study.

\section{Data collection}

Four forms were used to gather information on presenting clinical manifestations, diagnostic tests performed, number of days of hospitalization, surgical procedures, and treatments received by the patients, including prescription medications. An intake form was used to record information on the NCC-associated clinical manifestation(s) that caused the patient to be referred to the hospital. A diagnostic and treatment form was used to record information on techniques employed for the confirmation of NCC and the medications and procedures used for its treatment. Inpatient and outpatient forms were used to record information on the number of times the patients were hospitalized or had an outpatient appointment for the treatment and management of NCC.

Direct costs associated with pre-hospitalization, hospitalization, and post-hospitalization of NCC patients

Diagnosis and treatment-related costs were calculated for the pre-hospitalization, hospitalization, and post-hospitalization periods, beginning with the first NCC-associated visit to the INNN. The frequency of appointments with various healthcare providers (neurologists, neurosurgeons, psychiatrists, neurootologists, and general practitioners), prescription medication use, hospitalizations, surgical interventions, and diagnostic testing (CT scans, MRI, cerebral spinal fluid (CSF) testing, enzyme-linked immunosorbent assays (ELISA), enzyme-linked immunoelectrotransfer blot (EITB), biopsies, electroencephalograms (EEG), and neurological examinations) performed before, during, and after hospitalization were obtained using the forms described above. Initial visits to the INNN prior to the first NCC-associated hospitalization were included in the prehospitalization cost estimation. Healthcare services received at the INNN between two hospitalizations contributed to post-hospitalization costs for patients hospitalized more than once.

The cost of physician's office visits, diagnostic tests, a one-day stay in the hospital, and surgery were obtained from the year 2006 price list for healthcare services at the INNN ${ }^{19}$. The year 2006 tariffs were used due to their availability to the research personnel and to be in line with previous studies looking at NCC-related costs in Mexico ${ }^{9}$. Services for all patients included in the study were estimated in 2006 U.S. dollars (US\$) regardless of the date of hospitalization. The prices used in this study are considered applicable to other healthcare facilities in Mexico. There are seven levels of payments at the INNN, where patients pay medical fees according to their household income. Patients with a very low household income (level 0) do not pay anything, and all costs associated with treatment are paid by the healthcare provider (HCP). Level 1-6 patients 
pay increasing amounts for procedures and services. Based on discussions with the hospital personnel, level 5 best represents the true cost to the healthcare system.

In order to estimate the costs associated with prescribed medications, a list of drugs along with their dosages were extracted from the medical records. Brand name drugs were noted if specifically stated in the medical record. Otherwise, the active ingredient was recorded. Medication costs were obtained from pharmacies in Mexico City, Mexico. When only the active ingredient was available, pharmacy costs could represent either a brand name or generic drug. In situations where more than one dosage was available, the dosage that best matched the dosage and formulation presented in the medical record was used. A list of the drugs' active ingredients, dosages, and year 2006 pharmacy prices is included as supplementary material (Annex 1). Some of these combinations are known to represent specific brands, while others may represent generic drugs. All patients seen at the INNN paid for their medications themselves. A list of surgical procedures and their associated costs is also included as supplementary material (Annex 2). An exchange rate for the year 2006 of 10.80 Mexican pesos to 1 U.S. dollar was used ${ }^{20}$.

\section{Statistical analysis}

Pre-hospitalization, hospitalization, and posthospitalization costs were determined for each patient, with the average cost per period calculated for all patients. Pre-hospitalization costs were obtained by adding the actual (level 5) costs associated with office visits to a physician, diagnostic testing, and pharmacy costs for prescription medications prior to the first hospitalization. Similarly, hospitalization costs were obtained by adding actual (level 5) costs associated with diagnostic testing performed during hospitalization, a hospital stay in a private or general ward, surgery, and pharmacy costs for prescription medications received during hospitalization. An individual patient's per day hospitalization cost was obtained by dividing the patient's total hospitalization cost by the number of hospitalization days. These costs were then averaged over the entire study population to obtain a mean per day hospitalization cost. Post-hospitalization costs were calculated by adding the actual (level 5) costs associated with office visits to a physician, diagnostic testing, and pharmacy costs for prescription medications received after the first hospitalization for NCC at the INNN.

Enrolled patients began receiving treatment for NCC at the INNN on various dates between 2002 and 2007. Therefore, at the beginning of the study, patients had been followed for differing lengths of time. Annual costs were assessed for up to five years post-hospitalization based on the date of treatment initiation at the INNN. Only patients followed for at least 12 months after hospitalization were included in any post-hospitalization costs estimates. For patients with more than one recorded hospitalization, post-hospitalization out-patient costs were assessed from the date of the first hospitalization for NCC until the date of data collection.

Average per-patient level 5 costs were calculated for the entire study population as well as stratified by presenting clinical manifestation(s). The average costs that the patients paid during the pre-hospitalization, hospitalization, and post-hospitalization periods were also obtained using the payment levels and prescription medication costs. The average per-patient cost for each clinical manifestation grouping was then compared across the pre-hospitalization, hospitalization, and post-hospitalization periods using a repeated measures ANOVA, with post hoc pairwise comparisons made using Tukey's method. The above comparisons were made for all patients followed at least one year post-hospitalization. For patients followed at least 3 years post-hospitalization, the average treatment costs for the first, second, and third years post-hospitalization were compared using a repeated measures ANOVA, with post hoc pairwise comparisons conducted using the Tukey method. A t-test was used to compare the average per-patient hospitalization cost for patients who had a history of surgery with those who did not receive surgery. As the number of observations was small after stratifying the patients based on clinical manifestation(s), variances of the cost estimates were calculated using bootstrap techniques. The obtained variances were then used to calculate the 95\% confidence intervals (95\% CIs) for the average annual costs. All calculations were performed using Stata (Stata Statistical Software: Release 11.2. College Station, TX: StataCorp LP). A p-value $<0.05$ was considered statistically significant.

\section{Ethical approval}

This study received IRB approval from the Texas A\&M University (2006-0606 and 2014-0702) and the INNN.

\section{RESULTS}

\section{Patient demographics}

Among the 163 outpatients recruited, 108 had been hospitalized between 2002 and 2007 and 18 of these patients were hospitalized more than once. Patients were 
primarily from the State of Mexico (41\%) and Mexico City $(25 \%)$. The demographic characteristics of the hospitalized patients are shown in Table 1. The median age at the time of first hospitalization for NCC at the INNN was 42 years old and ranged from 19 to 84 years old. Almost half of the hospitalized patients were male $(48 \%)$. The number of hospitalized days ranged from 2 to 56 per patient. The lengths of time the patients were treated at the INNN prehospitalization and post-hospitalization ranged from 0 days to 5 years and 1 month to 5 years, respectively. Fifty percent of patients paid at level 2 , with no patients assigned to level 0 (Table 1).

\section{Clinical manifestations}

The most common clinical manifestations reported were severe chronic headaches (21\%), hydrocephalus (19\%), and the combination of hydrocephalus and severe chronic headaches (29\%) (Figure 1).

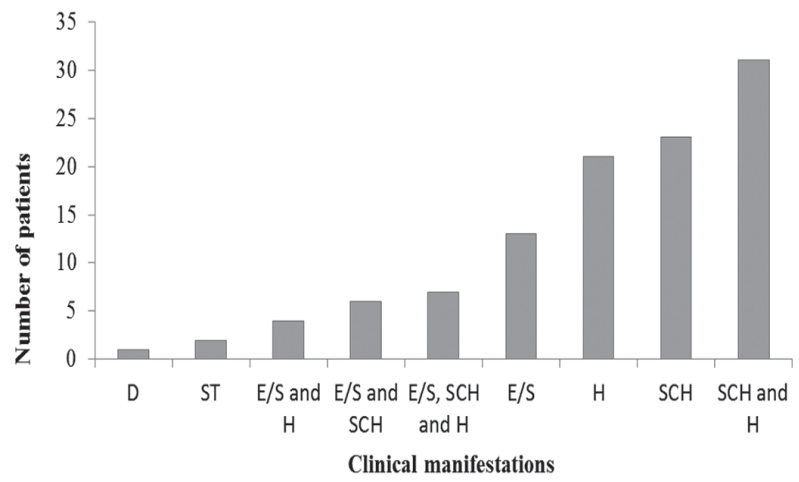

Figure 1 - NCC-related clinical manifestations of study patients. $\mathrm{E} / \mathrm{S}=$ Epilepsy/seizures, $\mathrm{H}=$ Hydrocephalus, $\mathrm{SCH}=$ Severe chronic headaches, ST = Stroke, D = Dementia

Table 1 - Demographic features of the 108 NCC patients hospitalized at the INNN from 2002 to 2007

\begin{tabular}{|c|c|c|c|c|c|c|c|}
\hline Category & $\begin{array}{r}\text { Level } 1 \\
(\mathrm{n}=37)\end{array}$ & $\begin{array}{c}\text { Level } 2 \\
(\mathrm{n}=54)\end{array}$ & $\begin{array}{c}\text { Level } 3 \\
(\mathrm{n}=9)\end{array}$ & $\begin{array}{c}\text { Level } 4 \\
(\mathrm{n}=1)\end{array}$ & $\begin{array}{c}\text { Level } 5 \\
(\mathrm{n}=3)\end{array}$ & $\begin{array}{c}\text { Level } 6 \\
(\mathrm{n}=4)\end{array}$ & $\begin{array}{c}\text { Total } \\
(\mathrm{n}=108)\end{array}$ \\
\hline $\begin{array}{l}\text { Number of patients who were hospitalized } \\
\text { more than once }\end{array}$ & 9 & 8 & 0 & 0 & 0 & 1 & 18 \\
\hline $\begin{array}{l}\text { Number of patients who did not receive pre- } \\
\text { hospitalization treatment at the INNN }\end{array}$ & 16 & 11 & 4 & 0 & 1 & 1 & 33 \\
\hline $\begin{array}{l}\text { Number of patients who received } 1 \text { to } 30 \text { days } \\
\text { of pre-hospitalization treatment at the INNN }\end{array}$ & 10 & 22 & 2 & 0 & 1 & 1 & 36 \\
\hline $\begin{array}{l}\text { Number of patients who received } 31 \text { to } 180 \\
\text { days of pre-hospitalization treatment at the } \\
\text { INNN }\end{array}$ & 5 & 7 & 2 & 1 & 0 & 0 & 15 \\
\hline $\begin{array}{l}\text { Number of patients who received } 181 \text { to } \\
365 \text { days of pre-hospitalization treatment } \\
\text { at the INNN }\end{array}$ & 2 & 2 & 0 & 0 & 1 & 0 & 5 \\
\hline $\begin{array}{l}\text { Number of patients who received } 1 \text { to } 2 \text { years } \\
\text { of pre-hospitalization treatment at the INNN }\end{array}$ & 1 & 3 & 1 & 0 & 0 & 1 & 6 \\
\hline $\begin{array}{l}\text { Number of patients who received more } \\
\text { than } 2 \text { years, but less than } 3 \text { years of pre- } \\
\text { hospitalization treatment the INNN }\end{array}$ & 1 & 3 & 0 & 0 & 0 & 1 & 5 \\
\hline $\begin{array}{l}\text { Number of patients who received more } \\
\text { than } 3 \text { years, but less than } 4 \text { years of pre- } \\
\text { hospitalization treatment at the INNN }\end{array}$ & 1 & 2 & 0 & 0 & 0 & 0 & 3 \\
\hline $\begin{array}{l}\text { Number of patients who received more } \\
\text { than } 4 \text { years, but less than } 5 \text { years of pre- } \\
\text { hospitalization treatment at the INNN }\end{array}$ & 1 & 4 & 0 & 0 & 0 & 0 & 5 \\
\hline $\begin{array}{l}\text { Number of patients with records available for } \\
\text { at least } 1 \text { year post-hospitalization }\end{array}$ & 31 & 43 & 7 & 1 & 2 & 2 & 86 \\
\hline $\begin{array}{l}\text { Number of patients with records available for } \\
\text { at least } 2 \text { years post-hospitalization }\end{array}$ & 19 & 25 & 7 & 1 & 2 & 1 & 55 \\
\hline $\begin{array}{l}\text { Number of patients with records available for } \\
\text { at least } 3 \text { years post-hospitalization }\end{array}$ & 14 & 17 & 7 & 0 & 2 & 1 & 41 \\
\hline $\begin{array}{l}\text { Number of patients with records available for } \\
\text { at least } 4 \text { years post-hospitalization }\end{array}$ & 8 & 12 & 5 & 0 & 1 & 0 & 26 \\
\hline $\begin{array}{l}\text { Number of patients with records available for } \\
5 \text { years post-hospitalization }\end{array}$ & 4 & 7 & 4 & 0 & 0 & 0 & 15 \\
\hline
\end{tabular}

* Note: No patient paid at level 0 . 
Estimation of pre-hospitalization, hospitalization, and post-hospitalization costs

Hospitalization costs were significantly higher compared to the costs incurred during the pre-hospitalization or complete post-hospitalization periods for all clinical manifestations except for epilepsy and stroke (Table 2).

\section{Pre-hospitalization costs}

The average actual (level 5) per-patient prehospitalization cost was US\$ 257 (95\% CI: $185-329$ ). Diagnostic testing made up $81 \%$ of this cost, followed by office visits to a physician (10\%) and prescription medications (9\%). The average pre-hospitalization cost paid for by the patients was US\$ 62 (95\% CI: $32-92)$. Table 3 shows the average per-patient pre-hospitalization costs by presenting clinical manifestation(s). No significant difference was found in the per-patient pre-hospitalization costs for the various clinical manifestation(s) $(\mathrm{p}=0.75)$. Overall, thirty-one percent of patients did not receive pre-hospitalization treatment. Since few patients received pre-hospitalization treatment for more than 30 days, stratification by the duration of pre-hospitalization care was not conducted.

\section{Hospitalization costs}

The average actual (level 5) per-patient hospitalization cost was US\$ 2,576 (95\% CI: 2,244 - 2,908), with an average per-patient per-day hospitalization cost of US\$ 269 (95\% CI: 218 - 320). The average total hospitalization cost paid for by the patients was US\$ 424 (95\% CI: 247 - 602), with an average daily cost of US\$ 67 (95\% CI: 6 - 128) (Table 4). Figure 2 shows the average perpatient per-day hospitalization cost by presenting clinical manifestation(s). No significant difference was found in the per-patient hospitalization costs for the various presenting clinical manifestation(s) $(\mathrm{p}=0.13)$. However, the cost of hospitalization was significantly higher in patients who had surgery $(\mathrm{n}=66)$ (US\$ 3,487) compared to those who did not have surgery $(\mathrm{n}=42)$ (US $\$ 1,166)$ $(\mathrm{p}<0.001)$. While $67 \%$ of NCC patients with clinical manifestations other than epilepsy underwent surgical procedures during hospitalization, only $23 \%$ of epilepsy patients had surgery.

Table 2 - Comparison of average pre-hospitalization, hospitalization, and total post-hospitalization costs for NCC patients treated at the INNN between 2002 and 2006 (2006 US\$) by clinical manifestation(s)

\begin{tabular}{|c|c|c|c|c|c|}
\hline Clinical Manifestation(s) & Pre-hospitalization & Hospitalization & Post-hospitalization & $p$-value & Overall $p$-value \\
\hline \multirow{3}{*}{ Epilepsy/seizures $(n=11)$} & 191 & 1,397 & & 0.00 & 0.00 \\
\hline & 191 & & 1,258 & 0.00 & \\
\hline & & 1,397 & 1,258 & 0.88 & \\
\hline \multirow{3}{*}{ Hydrocephalus ( $n=16$ ) } & 155 & 1,983 & & 0.00 & 0.00 \\
\hline & 155 & & 663 & 0.06 & \\
\hline & & 1,983 & 663 & 0.00 & \\
\hline \multirow{3}{*}{$\begin{array}{l}\text { Severe chronic headaches } \\
(\mathrm{n}=21)\end{array}$} & 306 & 2,089 & & 0.00 & 0.00 \\
\hline & 306 & & 806 & 0.18 & \\
\hline & & 2,089 & 806 & 0.00 & \\
\hline \multirow{3}{*}{ Stroke $(n=2)$} & 269 & 4,007 & & 0.38 & 0.36 \\
\hline & 269 & & 1,054 & 0.94 & \\
\hline & & 4,007 & 1,054 & 0.51 & \\
\hline \multirow{3}{*}{$\begin{array}{l}\text { Epilepsy/seizures and severe } \\
\text { chronic headaches }(n=6)\end{array}$} & 448 & 3,050 & & 0.00 & 0.02 \\
\hline & 448 & & 872 & 0.7 & \\
\hline & & 3,050 & 872 & 0.01 & \\
\hline \multirow{3}{*}{$\begin{array}{l}\text { Epilepsy/seizures and } \\
\text { hydrocephalus }(n=4)\end{array}$} & 119 & 4,544 & & 0.00 & 0.04 \\
\hline & 119 & & 711 & 0.85 & \\
\hline & & 4,544 & 711 & 0.01 & \\
\hline \multirow{3}{*}{$\begin{array}{l}\text { Severe chronic headaches } \\
\text { and hydrocephalus }(n=22)\end{array}$} & 290 & 3,022 & & 0.00 & 0.00 \\
\hline & 290 & & 769 & 0.28 & \\
\hline & & 3,022 & 769 & 0.00 & \\
\hline \multirow{3}{*}{$\begin{array}{l}\text { Epilepsy/seizures, severe } \\
\text { chronic headaches, and } \\
\text { hydrocephalus }(n=4)\end{array}$} & 213 & 3,488 & & 0.00 & 0.03 \\
\hline & 213 & & 539 & 0.94 & \\
\hline & & 3,488 & 539 & 0.00 & \\
\hline
\end{tabular}


Table 3 - Average actual (level 5) per-patient pre-hospitalization costs (2006 US\$) for NCC patients treated at the INNN between 2002 and 2006 by clinical manifestation(s) (values in brackets represent $95 \% \mathrm{Cl}$ )

\begin{tabular}{|c|c|c|c|c|c|}
\hline \multirow[b]{2}{*}{ Clinical manifestation(s) } & \multirow{2}{*}{$\begin{array}{l}\text { Number of } \\
\text { patients }\end{array}$} & \multicolumn{4}{|c|}{ Per-patient pre-hospitalization costs $(95 \% \mathrm{Cl})$} \\
\hline & & $\begin{array}{l}\text { Diagnostic } \\
\text { tests }\end{array}$ & $\begin{array}{l}\text { Physician office } \\
\text { visits }\end{array}$ & $\begin{array}{l}\text { Prescription } \\
\text { medications }\end{array}$ & Total \\
\hline Epilepsy/seizures & 13 & $\begin{array}{c}156 \\
(10-303)\end{array}$ & $\begin{array}{c}12 \\
(0-32)\end{array}$ & $\begin{array}{c}28 \\
(4-52)\end{array}$ & $\begin{array}{c}196 \\
(8-402)\end{array}$ \\
\hline Hydrocephalus & 21 & $\begin{array}{c}134 \\
(44-226)\end{array}$ & $\begin{array}{c}10 \\
(1-19)\end{array}$ & $\begin{array}{c}7 \\
(2-12)\end{array}$ & $\begin{array}{c}152 \\
(58-246)\end{array}$ \\
\hline Severe chronic headaches & 23 & $\begin{array}{c}239 \\
(75-403)\end{array}$ & $\begin{array}{c}24 \\
(4-44)\end{array}$ & $\begin{array}{c}24 \\
(0-64)\end{array}$ & $\begin{array}{c}287 \\
(106-470)\end{array}$ \\
\hline Stroke & 2 & $\begin{array}{c}269 \\
(181-356)\end{array}$ & 0 & 0 & $\begin{array}{c}269 \\
(181-356)\end{array}$ \\
\hline Dementia & 1 & 0 & 60 & 0 & 60 \\
\hline $\begin{array}{l}\text { Severe chronic headaches and } \\
\text { hydrocephalus }\end{array}$ & 31 & $\begin{array}{c}270 \\
(143-397)\end{array}$ & $\begin{array}{c}49 \\
(13-84)\end{array}$ & $\begin{array}{c}12 \\
(0-26)\end{array}$ & $\begin{array}{c}331 \\
(166-495) \\
\end{array}$ \\
\hline Epilepsy/seizures and hydrocephalus & 4 & $\begin{array}{c}108 \\
(10-207)\end{array}$ & $\begin{array}{c}5 \\
(0-10)\end{array}$ & $\begin{array}{c}6 \\
(0-13)\end{array}$ & $\begin{array}{c}119 \\
(15-223)\end{array}$ \\
\hline $\begin{array}{l}\text { Epilepsy/seizures and severe chronic } \\
\text { headaches }\end{array}$ & 6 & $\begin{array}{c}263 \\
(0-528)\end{array}$ & $\begin{array}{c}46 \\
(0-112)\end{array}$ & $\begin{array}{c}139 \\
(0-334)\end{array}$ & $\begin{array}{c}448 \\
(0-938)\end{array}$ \\
\hline $\begin{array}{l}\text { Epilepsy/seizures, severe chronic } \\
\text { headaches, and hydrocephalus }\end{array}$ & 7 & $\begin{array}{c}183 \\
(51-316) \\
\end{array}$ & $\begin{array}{c}17 \\
(0-42)\end{array}$ & 0 & $\begin{array}{c}200 \\
(43-355) \\
\end{array}$ \\
\hline Overall & 108 & $\begin{array}{c}210 \\
(152-270)\end{array}$ & $\begin{array}{c}26 \\
(15-39)\end{array}$ & $\begin{array}{c}21 \\
(3-40)\end{array}$ & $\begin{array}{c}257 \\
(185-329)\end{array}$ \\
\hline
\end{tabular}

Table 4 - Average actual (level 5) per-patient hospitalization costs (2006 US\$) for NCC patients treated at the INNN between 2002 and 2006 by clinical manifestation(s) (values in brackets represent $95 \% \mathrm{Cl}$ )

\begin{tabular}{|c|c|c|c|c|c|c|}
\hline \multirow[b]{2}{*}{ Clinical manifestation(s) } & \multirow{2}{*}{$\begin{array}{c}\text { Number } \\
\text { of patients } \\
\text { (Number of } \\
\text { hospitalizations) }\end{array}$} & \multicolumn{5}{|c|}{ Per-patient hospitalization costs $(95 \% \mathrm{Cl})$} \\
\hline & & $\begin{array}{l}\text { Diagnostic } \\
\text { tests }\end{array}$ & Hospital stay & Surgery & $\begin{array}{l}\text { Prescription } \\
\text { medications }\end{array}$ & $\begin{array}{c}\text { Total } \\
\text { hospitalization }\end{array}$ \\
\hline Epilepsy/seizures & $13(13)$ & $\begin{array}{c}177 \\
(100-253)\end{array}$ & $\begin{array}{c}1,026 \\
(655-1,397)\end{array}$ & $\begin{array}{c}429 \\
(5-853)\end{array}$ & $\begin{array}{c}107 \\
(0-220)\end{array}$ & $\begin{array}{c}1,739 \\
(926-2,552)\end{array}$ \\
\hline Hydrocephalus & $21(24)$ & $\begin{array}{c}186 \\
(99-273)\end{array}$ & $\begin{array}{c}803 \\
(570-1,037)\end{array}$ & $\begin{array}{c}1561 \\
(947-2,176)\end{array}$ & $\begin{array}{c}13 \\
(2-24)\end{array}$ & $\begin{array}{c}2,565 \\
(1,787-3,342)\end{array}$ \\
\hline Severe chronic headaches & $23(25)$ & $\begin{array}{c}297 \\
(198-396)\end{array}$ & $\begin{array}{c}758 \\
(585-930)\end{array}$ & $\begin{array}{c}882 \\
(382-1,382) \\
\end{array}$ & $\begin{array}{c}24 \\
(7-42)\end{array}$ & $\begin{array}{c}1,961 \\
(1,427-2,496)\end{array}$ \\
\hline Stroke & $2(2)$ & $\begin{array}{c}229 \\
(31-427)\end{array}$ & $\begin{array}{c}2,416 \\
(441-4,393)\end{array}$ & $\begin{array}{c}1,278 \\
(90-2,468)\end{array}$ & $\begin{array}{c}82 \\
(11-154)\end{array}$ & $\begin{array}{c}4,007 \\
(467-7,548)\end{array}$ \\
\hline Dementia & $1(1)$ & 469 & 748 & 0 & 99 & 1,316 \\
\hline $\begin{array}{l}\text { Severe chronic headaches } \\
\text { and hydrocephalus }\end{array}$ & $31(44)$ & $\begin{array}{c}197 \\
(115-280)\end{array}$ & $\begin{array}{c}874 \\
(664-1,084) \\
\end{array}$ & $\begin{array}{c}1,782 \\
(1,245-2,318)\end{array}$ & $\begin{array}{c}28 \\
(10-47) \\
\end{array}$ & $\begin{array}{c}2,882 \\
(2,265-3,499) \\
\end{array}$ \\
\hline $\begin{array}{l}\text { Epilepsy/seizures and } \\
\text { hydrocephalus }\end{array}$ & $4(9)$ & $\begin{array}{c}481 \\
(154-809)\end{array}$ & $\begin{array}{c}1,276 \\
(680-1,872)\end{array}$ & $\begin{array}{c}2,771 \\
(1,289-4,253)\end{array}$ & $\begin{array}{c}14 \\
(0-33)\end{array}$ & $\begin{array}{c}4,544 \\
(2,241-6,847\end{array}$ \\
\hline $\begin{array}{l}\text { Epilepsy/seizures and } \\
\text { severe chronic headaches }\end{array}$ & $6(10)$ & $\begin{array}{c}433 \\
(115-749) \\
\end{array}$ & $\begin{array}{c}1,316 \\
(869-1,763) \\
\end{array}$ & $\begin{array}{c}1,279 \\
(447-2,110) \\
\end{array}$ & $\begin{array}{c}22 \\
(9-35)\end{array}$ & $\begin{array}{c}3,050 \\
(1,803-4,296) \\
\end{array}$ \\
\hline $\begin{array}{l}\text { Epilepsy/seizures, severe } \\
\text { chronic headaches, and } \\
\text { hydrocephalus }\end{array}$ & $7(12)$ & $\begin{array}{c}472 \\
(310-634)\end{array}$ & $\begin{array}{c}904 \\
(531-1,277)\end{array}$ & $\begin{array}{c}1,819 \\
(451-3,187)\end{array}$ & $\begin{array}{c}38 \\
(24-52)\end{array}$ & $\begin{array}{c}3,223 \\
(1,866-4,579)\end{array}$ \\
\hline Overall & $108(140)$ & $\begin{array}{c}254 \\
(206-302)\end{array}$ & $\begin{array}{c}922 \\
(689-1,155)\end{array}$ & $\begin{array}{c}1,365 \\
(797-1,933)\end{array}$ & $\begin{array}{c}35 \\
(19-51)\end{array}$ & $\begin{array}{c}2,576 \\
(2,244-2,908)\end{array}$ \\
\hline
\end{tabular}




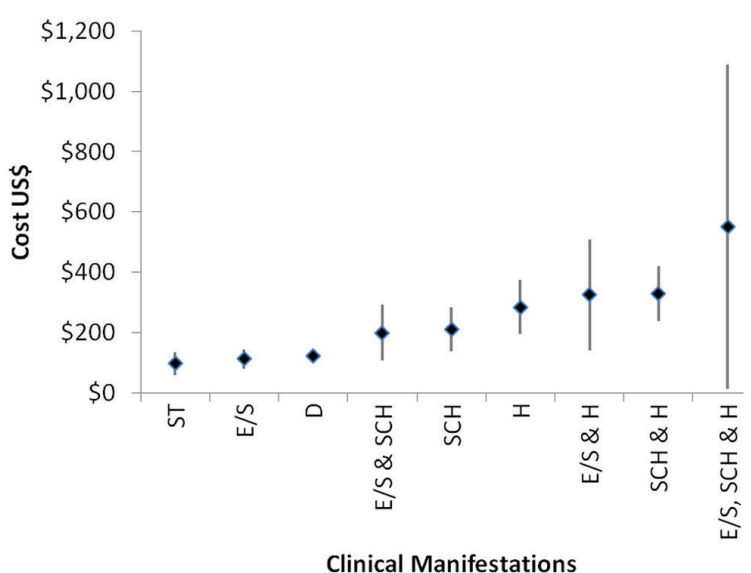

Figure 2 - Average actual (level 5) per-patient per-day hospitalization costs (US\$) for NCC patients treated at the INNN by clinical manifestation(s) (The plot whiskers extend to the upper and lower 95\% confidence intervals). E/S = Epilepsy/ seizures, $\mathrm{H}=$ Hydrocephalus, $\mathrm{SCH}=$ Severe chronic headaches, $\mathrm{ST}=$ Stroke, $\mathrm{D}=$ Dementia

\section{Post-hospitalization costs}

The average actual (level 5) per-patient costs for one to five years post-hospitalization were US\$ $475(95 \%$ CI: 423 - 527), US\$ 228 (95\% CI: 167 - 288), US\$ 157 (95\% CI: 111 - 202), US\$ 150 (95\% CI: 106 - 204), and US\$ 91 (95\% CI: 27 - 154), respectively (Table 5 and Figure 2). For patients followed up for at least 3 years post-hospitalization $(n=41)$, the average cost for the first post-hospitalization treatment year (US\$ 445) was significantly higher than that for the second year post-hospitalization (US\$ 316) $(\mathrm{p}=0.05)$, which in turn was not significantly higher than that for the third year post-hospitalization (US\$239) ( $\mathrm{p}=0.35)$. No significant difference was found in the per-patient costs for the various clinical manifestation(s) for the post-hospitalization period $(\mathrm{p}=0.37)$ (Table 5). Figure 3 shows the average posthospitalization costs broken down by the cost components of diagnostic testing, visits to a healthcare provider, and prescription medications. The costs paid for by the patients for one to five years post-hospitalization were US\$ 114 (95\% CI: 88 - 141), US\$ 56 (95\% CI: $32-80)$, US\$ 47 (95\% CI: 25 - 69), US\$ 45 (95\% CI: $17-74)$, and US\$ 32 (95\% CI: $0-66$ ), respectively. Most of these costs were due to prescription medications (Figure 4).

\section{DISCUSSION}

This is the first patient-based study estimating the direct monetary expenses associated with NCC-affected individuals in Mexico during the pre-hospitalization, hospitalization, and post-hospitalization periods. Overall, substantial costs were associated with patients requiring hospitalization for NCC, with this burden continuing years post-hospitalization. When all patients, regardless of

Table 5 - Average actual (level 5) per-patient post-hospitalization costs (2006 US\$) for NCC patients treated at the INNN between 2002 and 2006 by clinical manifestation(s) (values in brackets represent $95 \% \mathrm{Cl}$ )

\begin{tabular}{|c|c|c|c|c|c|}
\hline \multirow[t]{2}{*}{ Clinical manifestations } & \multicolumn{5}{|c|}{$\begin{array}{c}\text { Per-patient post-hospitalization costs }(95 \% \mathrm{Cl}) \text {, } \\
\text { (number of patients) }\end{array}$} \\
\hline & $1^{\text {st }}$ year & $2^{\text {nd }}$ year & $3^{\text {rd }}$ year & $4^{\text {th }}$ year & $5^{\text {th }}$ year \\
\hline Epilepsy/ seizures & $\begin{array}{c}648(421-874) \\
(n=11)\end{array}$ & $\begin{array}{c}319(66-574) \\
(n=9)\end{array}$ & $\begin{array}{c}220(65-376) \\
(n=6)\end{array}$ & $\begin{array}{c}207\left(\begin{array}{c}(44-398) \\
(n=4)\end{array}\right. \\
\end{array}$ & $\begin{array}{l}197 \\
(n=1)\end{array}$ \\
\hline Hydrocephalus & $\begin{array}{c}480(369-591) \\
(n=16)\end{array}$ & $\begin{array}{c}115(51-180) \\
(n=9)\end{array}$ & $\begin{array}{c}187(54-320) \\
(n=4)\end{array}$ & $\begin{array}{c}159(23-295) \\
(n=3)\end{array}$ & $\begin{array}{c}127(5-245) \\
(n=2)\end{array}$ \\
\hline Severe chronic headaches & $\begin{array}{c}474(357-592) \\
(n=21)\end{array}$ & $\begin{array}{c}302(173-432) \\
(n=11)\end{array}$ & $\begin{array}{c}176(78-275) \\
\quad(n=8)\end{array}$ & $\begin{array}{c}226(99-353) \\
(n=5)\end{array}$ & $\begin{array}{c}151(1-301) \\
(n=4)\end{array}$ \\
\hline Stroke & $\begin{array}{c}506(255-665) \\
(n=2)\end{array}$ & $\begin{array}{c}105(0-218) \\
(\mathrm{n}=2)\end{array}$ & $\begin{array}{c}238 \\
(n=1)\end{array}$ & $\begin{array}{c}304 \\
(n=1)\end{array}$ & $\begin{array}{c}209 \\
(\mathrm{n}=1)\end{array}$ \\
\hline Dementia* $^{*}$ & - & - & - & - & - \\
\hline $\begin{array}{l}\text { Severe chronic headaches and } \\
\text { hydrocephalus }\end{array}$ & $\begin{array}{c}461(379-542) \\
(n=22)\end{array}$ & $\begin{array}{c}244(136-352) \\
(n=15)\end{array}$ & $\begin{array}{c}145(84-206) \\
(n=13)\end{array}$ & $\begin{array}{c}67(16-118) \\
(n=10)\end{array}$ & $\begin{array}{c}20(1-38) \\
(n=6)\end{array}$ \\
\hline $\begin{array}{l}\text { Epilepsy/seizures and } \\
\text { hydrocephalus }\end{array}$ & $\begin{array}{c}450(328-571) \\
(n=4)\end{array}$ & $\begin{array}{c}167(46-291) \\
(n=3)\end{array}$ & $\begin{array}{c}134(0-291) \\
(n=2)\end{array}$ & $\begin{array}{c}124(0-275) \\
(n=2)\end{array}$ & $\begin{array}{l}20 \\
(n=1)\end{array}$ \\
\hline $\begin{array}{l}\text { Epilepsy/seizures and severe } \\
\text { chronic headaches }\end{array}$ & $\begin{array}{c}376(221-531) \\
(n=6)\end{array}$ & $\begin{array}{c}266(46-487) \\
(n=4)\end{array}$ & $\begin{array}{c}114(0-246) \\
(\mathrm{n}=4)\end{array}$ & $\begin{array}{c}215 \\
(n=1) \\
\end{array}$ & - \\
\hline $\begin{array}{l}\text { Epilepsy/seizures, severe chronic } \\
\text { headaches, and hydrocephalus }\end{array}$ & $\begin{array}{c}373(161-585) \\
(n=4)\end{array}$ & $\begin{array}{c}122(31-213) \\
(n=2)\end{array}$ & - & - & - \\
\hline Overall & $\begin{array}{c}475(423-527) \\
(n=86)\end{array}$ & $\begin{array}{c}228(167-288) \\
(n=55)\end{array}$ & 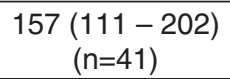 & $\begin{array}{c}150(106-204) \\
(n=26)\end{array}$ & $\begin{array}{c}91(27-154) \\
(n=15)\end{array}$ \\
\hline
\end{tabular}

* The dementia patient was followed for less than 12 months and was, therefore, not included in the estimation of post-hospitalization costs 


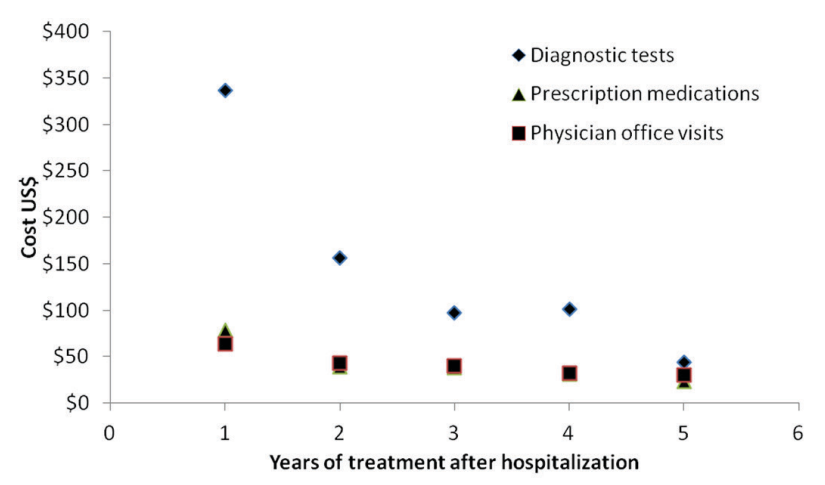

Figure 3 - Average costs broken down by cost component and year of treatment post-hospitalization for NCC patients treated at the INNN. Note: There were $86,55,41,26$, and 15 patients who received treatment one, two, three, four, and five years post-hospitalization, respectively

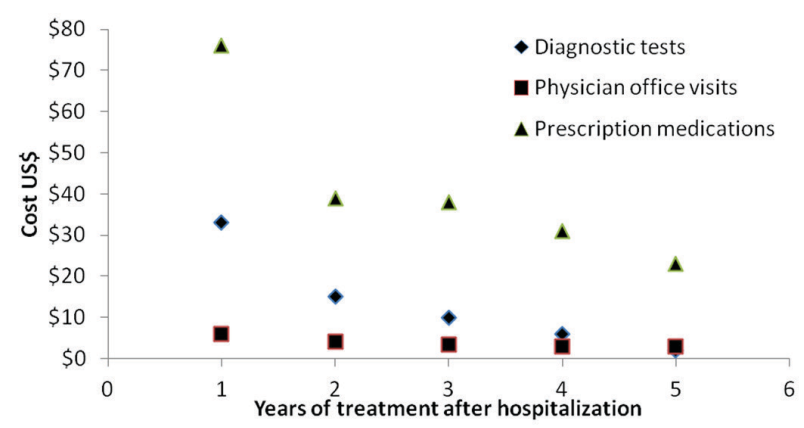

Figure 4 - Average costs paid by the patients, broken down by cost component and year of treatment post-hospitalization for NCC patients treated at the INNN. Note: There were 86,55 , 41,26 , and 15 patients who received treatment one, two, three, four, and five years post-hospitalization, respectively

having received pre-hospitalization care at the INNN, were included in the analysis, the direct economic expenses prehospitalization, during hospitalization, and during the first year post-hospitalization were equivalent to $22 \%, 224 \%$, and $42 \%$ of an annual minimum wage salary in Mexico (US\$ 1,145), respectively ${ }^{21}$. Overall, pre-hospitalization represented the least expensive cost period for patients. However, pre-hospitalization costs increased from $22 \%$ to $32 \%$ of an annual minimum wage salary when only those patients with pre-hospitalization treatment were included ${ }^{21}$.

Very few studies have been conducted to estimate the cost associated with NCC patients. In the current study, patients incurred expenses equivalent to $64 \%$ of an annual minimum wage salary during the pre-hospitalization period plus one year post-hospitalization ${ }^{21}$. In comparison, nonhospitalized Indian patients with NCC-associated epilepsy were shown to spend $51 \%$ of their per capita gross national product (GNP) on direct and indirect costs associated with their disease during their treatment period, which ranged from 1 to 14 months ${ }^{14}$. Unfortunately, direct comparison between these two studies is difficult. Not only did the
Indian study use per capita GNP versus wage data, this study also restricted participants to only those NCC patients with epilepsy. Since the cost of prescription medications tends to be higher for epileptic patients with NCC compared to non-epileptic NCC patients, it would be expected that epileptics would incur higher costs. In our study, epileptic patients were spending twice as much on prescription medications compared to non-epileptic patients. If we consider only the epileptic patients in our study, economic expenses were equivalent to $72 \%$ of an annual minimum wage salary during pre-hospitalization plus the first year post-hospitalization. Another reason why these two studies are difficult to compare is that the Indian study also included indirect expenses whereas the current Mexican study did not. Productivity losses accounted for $17 \%$ of total costs associated with the Indian patients.

In another study conducted in a reference hospital in Peru, NCC patients were spending 54\% and $16 \%$ of an annual minimum wage salary on direct and indirect costs associated with their disease during their first year and second year of treatment, respectively ${ }^{13}$. This study included patients with and without epilepsy as well as hospitalized and non-hospitalized patients whereas the current study only included hospitalized patients. Overall, 78\% of the patients in the Peruvian study were hospitalized. The Peruvian patients spent a smaller proportion of a minimum wage salary on treatment costs compared to the Mexican patients. One possible reason for this difference is that $61 \%$ of the patients in the current study underwent surgery whereas none of the Peruvian patients underwent surgery. The prehospitalization, hospitalization, and post-hospitalization costs for the Mexican patients who did not have surgery were $16 \%, 100 \%$ and $66 \%$ of an annual minimum wage salary, respectively. Hospitalization and post-hospitalization values were, therefore, about $50 \%$ lower than for the entire studied population. It should be noted that the Peruvian study also included productivity losses, which were not assessed in the current Mexican study. Productivity losses accounted for $10 \%$ of total costs in the Peruvian study.

In the current study, the hospitalization period incurred higher per-patient costs for all clinical manifestations when compared to the pre-hospitalization or entire post-hospitalization period. However, this cost was not significantly higher for patients with epilepsy or stroke as the sole presenting clinical manifestation. In comparison to patients with other clinical manifestations, fewer epilepsy cases had surgery and the number of patients with stroke was very small, explaining the lack of significant differences for these two groups. The post-hospitalization costs were highest in the first year post-hospitalization, which was likely due to the greater number of diagnostic 
tests performed in this year as compared to subsequent years. The average number of hospitalized days for patients whose records were evaluated after they had received only one year of treatment post-hospitalization (11 days) was similar to patients whose records were evaluated after they had received more than one year of treatment posthospitalization (13 days). Therefore, the patient's clinical severity at the time of hospitalization did not greatly influence these values.

Although our results suggest that the actual cost to treat NCC is high compared to an annual minimum wage salary in Mexico, most patients in this study paid a reduced amount based on their income. The exception was for prescription medications. The vast majority $(83 \%)$ of patients paid at level 2 or below, which is well below the actual costs to the healthcare system, indicating that they fell into a lower income bracket. Although they paid a reduced amount compared to the actual price of services, they were still spending a considerable proportion of an annual minimum wage salary during the pre-hospitalization and hospitalization periods combined (43\%), and during the first year post-hospitalization (10\%). It should be noted that costs associated with treatment that were not paid by patients were absorbed by the hospital system and, therefore, by the society as a whole.

This study has some limitations. Data were collected from medical chart reviews, which limited the assessed variables to those recorded as part of the standard medical charting process and those anticipated to be of value prior to the beginning of this study. Therefore, type of NCC (intraparenchymal versus extraparenchymal), cyst viability, and actual wage data were not available for analysis. Our estimates are also an underestimate of the total costs associated with NCC among patients hospitalized at the INNN since indirect costs such as loss of working days due to visits to a healthcare provider or during hospitalization, cost of over-the-counter medication, cost of traditional medicine/treatment, reduction in productivity level, costs associated with transportation to and from medical treatment, and time lost by the patient's family to take care of them or to accompany them to treatment were not available for analysis ${ }^{22}$. In addition, this information excludes any costs incurred while receiving treatment in a healthcare facility other than the INNN, which could especially affect the estimated pre- and post-hospitalization costs. Finally, this study was conducted in a neurology reference hospital, which likely sees many of the more severe cases. Therefore, the determined costs cannot be extrapolated to all NCC cases in Mexico.

While the actual costs associated with healthcare services may change over time, the relative proportion of costs associated with the pre-hospitalization, hospitalization and post-hospitalization periods will likely remain more stable. Therefore, values presented in this study can be used by Mexico to better define the direct costs associated with NCC patients who are hospitalized at tertiary care hospitals, with the ultimate goal of better conveying the true economic impact of NCC to policy makers.

\section{ACKNOWLEDGMENTS}

We would like to thank all of the people involved in the collection of data in Mexico.

\section{FINANCIAL SUPPORT}

This work was funded by the Texas A\&M UniversityCONACYT Collaborative Research Grant Program. The open access publishing fees for this article have been covered by the Texas A\&M University Open Access to Knowledge Fund (OAKFund), supported by the University Libraries and the Office of the Vice President for Research.

\section{REFERENCES}

1. Rajshekhar V, Joshi DD, Doanh NQ van De N, Xiaonong Z. Taenia solium taeniosis/cysticercosis in Asia: epidemiology, impact and issues. Acta Trop. 2003;87:53-60.

2. Zoli A, Shey-Njila O, Assana E, Nguekam JP, Dorny P, Brandt J, et al. Regional status, epidemiology and impact of Taenia solium cysticercosis in Western and Central Africa. Acta Trop. 2003;87:35-42.

3. Flisser A, Sarti E, Lightowlers M, Schantz P. Neurocysticercosis: regional status, epidemiology, impact and control measures in the Americas. Acta Trop. 2003;87:43-51.

4. O'Keefe KA, Eberhard ML, Shafir SC, Wilkins P, Ash LR, Sorvillo FJ. Cysticercosis-related hospitalizations in the United States, 1998-2011. Am J Trop Med Hyg. 2015;92:354-9.

5. Del Brutto OH. A review of cases of human cysticercosis in Canada. Can J Neurol Sci. 2012;39:319-22.

6. Bruno E, Bartoloni A, Zammarchi L, Strohmeyer M, Bartalesi F, Bustos JA, et al. Epilepsy and neurocysticercosis in Latin America: a systematic review and meta-analysis. PLoS Negl Trop Dis. 2013; 7:e2480.

7. Bhattarai R, Budke CM, Carabin H, Proaño JV, Flores-Rivera $\mathrm{J}$, Corona $\mathrm{T}$, et al. Estimating the non-monetary burden of neurocysticercosis in Mexico. PLoS Negl Trop Dis. 2012;6:e1521.

8. Bhattarai R, Budke CM, Carabin H, Proaño JV, Flores-Rivera J, Corona T, et al. Quality of life in patients with neurocysticercosis in Mexico. Am J Trop Med Hyg. 2011;84:782-6. 
9. Bhattarai R, Carabin H, Proaño JV, Flores-Rivera J, Corona T, Flisser A, et al. Cost of neurocysticercosis patients treated in two referral hospitals in Mexico City, Mexico. Trop Med Int Health. 2015;20:1108-19.

10. Carabin H, Krecek RC, Cowan LD, Michael L, Foyaca-Sibat $\mathrm{H}$, Nash T, et al. Estimation of the cost of Taenia solium cysticercosis in Eastern Cape Province, South Africa. Trop Med Int Health. 2006;11:906-16.

11. Praet N, Speybroeck N, Manzanedo R, Berkvens D, Nsame Nforninwe D, Zoli A, et al. The disease burden of Taenia solium cysticercosis in Cameroon. PLoS Negl Trop Dis. 2009;3:e406.

12. Wallin MT, Pretell EJ, Bustos JA, Caballero M, Alfaro M, Kane R, et al. Cognitive changes and quality of life in neurocysticercosis: a longitudinal study. PLoS Negl Trop Dis 2012;6:e1493.

13. Rajkotia Y, Lescano AG, Gilman RH, Cornejo C, Garcia HH. Economic burden of neurocysticercosis: results from Peru. Trans R Soc Trop Med Hyg. 2007;101:840-6.

14. Murthy JM, Rajshekar G. Economic evaluation of seizures associated with solitary cysticercus granuloma. Neurol India. 2007;55:42-5.

15. Croker C, Reporter R, Mascola L. Use of statewide hospital discharge data to evaluate the economic burden of neurocysticercosis in Los Angeles County (1991-2008). Am
J Trop Med Hyg. 2010;83:106-10.

16. O'Neal SE, Flecker RH. Hospitalization frequency and charges for neurocysticercosis, United States, 2003-2012. Emerg Infect Dis. 2015;21:969-76.

17. Fica A, Weitzel T. Gastos hospitalarios en pacientes con fascioliasis en fase aguda, hidatidosis de tratamiento quirúrgico y neurocisticercosis en un hospital general en Chile. Rev Chilena Infectol. 2014;31:406-10.

18. Del Brutto OH, Rajshekhar V, White AC Jr, Tsang VC, Nash TE, Takayanagui OM, et al. Proposed diagnostic criteria for neurocysticercosis. Neurology. 2001;57:177-83.

19. México. Secretaría de Finanzas. Subsecretaría de Ingresos, Unidade de Política de Ingresos. Tabulador de cuotas de recuperación: Instituto Nacional de Neurología y Neurocirugía Manuel Velasco Suaréz. México: Secretaria de Finanzas; 2006.

20. OANDA Solutions for Business. Historical rates. [cited 2018 March 7]. Available from: https://www.oanda.com/fx-forbusiness/historical-rates

21. México. Secretaría del Trabajo y Previsión Social. Salarios mínimos vigentes a partir de $1^{\circ}$ de enero de 2006. [cited 2018 March 7]. Available from: http://www.conasami.gob.mx/pdf/ tabla_salarios_minimos/2006/01_01_31_12_2006.pdf

22. Bhattarai R, Carabin H, Budke CM. The burden of cysticercosis. In: Sibat HF, editor. Novel aspects on cysticercosis and neurocysticercosis. London: InTech; 2013. p.59-76. 
Annex 1 - List of drugs prescribed for NCC patients treated at the INNN between 2002 and 2006

\begin{tabular}{|c|c|c|}
\hline Drug Name & Dosage & $\begin{array}{c}\text { Pharmacy } \\
\text { price in US\$ }\end{array}$ \\
\hline Acetaminophen & $500 \mathrm{mg}$ & 0.08 \\
\hline Acetylsalicylic acid & $100 \mathrm{mg}$ & 0.07 \\
\hline Albendazole & $200 \mathrm{mg}$ & 0.69 \\
\hline Captopril & $25 \mathrm{mg}$ & 0.02 \\
\hline Carbamazepine & $200 \mathrm{mg}$ & 0.08 \\
\hline Cinnarizine & 75 mg & 0.83 \\
\hline Ciprofloxacin & $500 \mathrm{mg}$ & 0.35 \\
\hline Clobazam & 10 mg & 0.46 \\
\hline Clonazepam & $2.5 \mathrm{mg}$ & 0.04 \\
\hline Clonixin lysine-cyclobenzapine & $100 \mathrm{mg} / 2 \mathrm{ml}$ & 0.5 \\
\hline Dexamethasone & 8 mg/2 ml & 0.27 \\
\hline Enalapril & $10 \mathrm{mg}$ & 0.23 \\
\hline Fluoxetine & $20 \mathrm{mg}$ & 2.4 \\
\hline Galantamine & $4 \mathrm{mg}$ & 1.27 \\
\hline Ibuprofen & $400 \mathrm{mg}$ & 0.75 \\
\hline Ketorolac & $10 / 30 \mathrm{mg}$ & 0.12 \\
\hline Lamotrigine & $100 \mathrm{mg}$ & 1.41 \\
\hline Metoclopramide & $10 \mathrm{mg}$ & 0.03 \\
\hline Metronidazol & $500 \mathrm{mg}$ & 0.19 \\
\hline Nimodipine & $30 \mathrm{mg}$ & 0.96 \\
\hline Omeprazole & $20 / 40 \mathrm{mg}$ & $0.04 / 3.50$ \\
\hline Phenytoin & $100 / 250 \mathrm{mg}$ & $0.16 / 1.40$ \\
\hline Praziquantel & $600 \mathrm{mg}$ & 5.86 \\
\hline Prednisone & $5 \mathrm{mg} / 50 \mathrm{mg}$ & $0.02 / 0.10$ \\
\hline Primidone & $250 \mathrm{mg}$ & 0.16 \\
\hline Propanolol & 40 mg & 0.13 \\
\hline Quetiapine & $25 \mathrm{mg}$ & 0.77 \\
\hline Ranitidine & $150 / 300 \mathrm{mg}$ & $0.10 / 0.15$ \\
\hline Topiramate & 100 mg & 1.93 \\
\hline Valproic acid & $200 \mathrm{mg}$ & 0.11 \\
\hline Vigabatrin & $300 \mathrm{mg}$ & 0.53 \\
\hline
\end{tabular}

Annex 2 - List of surgical procedures performed on NCC patients treated at the INNN between 2002 and 2006

\begin{tabular}{lc}
\hline Type of Surgery & $\begin{array}{c}\text { Level 5 } \\
\text { Cost in US\$ }\end{array}$ \\
\hline Close up ventriculostomy & 71 \\
Craniotomy & 2,389 \\
Cysticercosis removal/resection & 1,535 \\
Endoscopic exploration & 307 \\
Laminectomy & 2,507 \\
Replacement/removal of vericulo-peritoneal & 1,023 \\
shunt & \\
Valve replacement & 1,023 \\
Valvular dysfunction & 1,023 \\
Ventriculoperitoneal shunt placement & 1,535 \\
Ventriculostomy & 511 \\
\hline
\end{tabular}

